\title{
Seasonal changes in ciliate biomass and composition of the ciliate community in oligo-mesotrophic Lake Jasne (Iława Lake District, Poland)
}

\author{
Natalia Czychewicz, Krzysztof Rychert*
}

Department of Aquatic Ecology, Pomeranian University in Słupsk, Arciszewskiego 22b, 76-200 Słupsk, Poland, *e-mail: krychert@wp.pl

\begin{abstract}
Lake Jasne, also known as Lake Czyste, is a well-known oligo-mesotrophic water body located in the Iława Lake District, Poland. Between May 2009 and June 2010 ciliate biomass and community composition were studied on the basis of Lugol-fixed samples taken from the surface waters and the near-bottom zone. The mean annual ciliate biomass amounted to $0.58 \mu \mathrm{gC} \mathrm{l}^{-1}$ in the surface waters and $1.46 \mu \mathrm{gC} \mathrm{l}^{-1}$ in the near-bottom zone, and therefore, the ciliate biomass is amongst the lowest estimates observed in oligotrophic waters. In the surface waters typical bimodal seasonal changes in biomass were recorded with two peaks observed in spring and autumn. In the near-bottom zone the peak was recorded only in spring. The ciliate community was dominated by prostomatids (mainly Urotricha spp.), both in the surface waters (77\% of biomass) and in the near-bottom zone (54\% of biomass).
\end{abstract}

Keywords: planktonic ciliates, oligotrophy, Lake Jasne

\section{Introduction}

Since the description of the so-called microbial loop (Azam et al. 1983) intensive studies on planktonic ciliates have been carried out. Almost thirty years of studies have resulted in the determination of the abundance, biomass, and taxonomic composition of ciliate communities observed in water bodies of different trophic state. Ciliates' abundance increases with the trophic state of the water (Beaver and Crisman 1982). In oligotrophic waters ciliate communities are dominated by large oligotrichs feeding on nanoplankton (mainly algae). In eutrophic waters abundance of bacterivorous ciliates (scuticociliates or small oligotrichs) increases (Beaver and Crisman 1982; Šimek et al. 2000).

The aim of the study was to describe seasonal changes in biomass and composition of the ciliate community in oligo-mesotrophic Lake Jasne, which is characterised by clear and very transparent waters.

\section{Methods}

Sampling was carried out at the deepest place of the lake between $16^{\text {th }}$ May 2009 and $4^{\text {th }}$ June 2010.
Water was taken from the surface and the near-bottom zone (altogether 22 samples were taken), fixed with acid Lugol's solution (end concentration: 1\%), and analysed under an inverted microscope with the Utermöhl method (1958). Ciliates were counted, identified with the guide by Foissner and Berger (1996), and measured with the use of the software for image analysis. Biomass was estimated with the use of

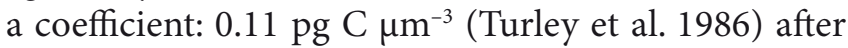
calculating the volume of each ciliate cell. Typically, ciliate abundance was low, and therefore, 50 or even $100 \mathrm{ml}$ of water was examined. Each sampling was accompanied with measurements of water temperature and water transparency (the Secchi depth).

\section{Study area description}

Lake Jasne (also known as Lake Czyste) is located in the Iława Lake District Landscape Park (Northern Poland; $53^{\circ} 44.5^{\prime} \mathrm{N} ; 1^{\circ} 33.1^{\prime} \mathrm{E}$ ). Lake Jasne is surrounded by forest. Its area amounts to 10.6 ha. The maximum and mean depths reach 22.0 and $9.3 \mathrm{~m}$, respectively (Jańczak 1997). Macrophytes in the littoral zone are poorly-developed. The lake shows high water 
transparency (the Secchi depth 9-11 m) and low pH of the water: 4.0-4.8 (Burkowska and Donderski 2006). The concentrations of total phosphorus and total nitrogen are $0.05 \mathrm{mg} \mathrm{P} \mathrm{l}^{-1}$ and $0.5 \mathrm{mg} \mathrm{N} \mathrm{l}^{-1}$, respectively (Swiontek-Brzezinska and Donderski 2006).

\section{Results and discussion}

The temperature of the surface waters ranged from a few degrees centigrade (under the ice cover in winter) to $22^{\circ} \mathrm{C}$ in summer, and that range was typical of temperate waters. During summer the standard thermal stratification was observed. The Secchi depth ranged from $6 \mathrm{~m}$ (the bloom of cryptophytes, $18^{\text {th }}$ March 2010) to $14.5 \mathrm{~m}$ (clear water phase, $27^{\text {th }}$ June 2009).

The mean annual ciliate biomass, calculated as the weighted mean, amounted to $0.58 \mu \mathrm{g} \mathrm{Cl}^{-1}$ (3.5 cells $\left.\mathrm{ml}^{-1}\right)$ in the surface waters, and $1.46 \mu \mathrm{g} \mathrm{Cl}^{-1}$ (7.4 cells $\mathrm{ml}^{-1}$ ) in the near-bottom zone. The authors applied the weighted mean because the periods between sampling dates were different. The obtained values are amongst the lowest estimates observed in oligotrophic lakes: temperate e.g. Huron and Michigan $(5.0 \mu \mathrm{g} \mathrm{C}$ $\mathrm{l}^{-1}, 7.0$ cells $\mathrm{ml}^{-1}$, Carrick and Fahnenstiel 1990), subtropical e.g. Lake Blue Cypress $\left(6.6 \mu \mathrm{g} \mathrm{C}^{-1}\right.$, biomass recalculated with a coefficient $0.11 \mathrm{pg} \mathrm{C} \mu \mathrm{m}^{-3}, 3.1$ cells $\mathrm{ml}^{-1}$, Beaver and Crisman 1982), and tropical e.g. Lake

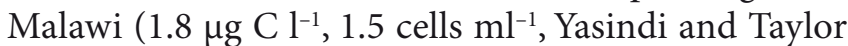
2003). Such low ciliate biomass is observed in surface oceanic waters e.g. the Oregon coastal waters $(0.8 \mu \mathrm{g}$ $\mathrm{C}^{-1}, 1.3$ cells $\mathrm{ml}^{-1}$, Sherr and Sherr 2002).

In the surface waters of Lake Jasne seasonal changes were bimodal with the spring peak recorded in April-May and the autumn peak observed in September-November (Fig. 1.). The peak observed in autumn was associated with the bloom of cryptophytes (up to 899 cells $\mathrm{ml}^{-1}, 185 \mu \mathrm{g} \mathrm{Cl}^{-1}$, mainly Cryptomonas rostrata). The ciliate community was dominated, also during the peaks, by small prostomatids ( $77 \%$ of biomass, mainly Urotricha spp.). Oligotrichs constituted only $4 \%$ of the total biomass, whereas $19 \%$ included ciliates of other orders and unidentified ones. All the contributions to the biomass were calculated as the weighted mean for the whole year. In the near-bottom waters only one peak was observed during the spring 2010, when the ciliate biomass in the near-bottom zone exceeded tenfold the biomass in the surface waters. Initially, that peak comprised prostomatids (mainly Urotricha spp.), followed by peritrichs (main-

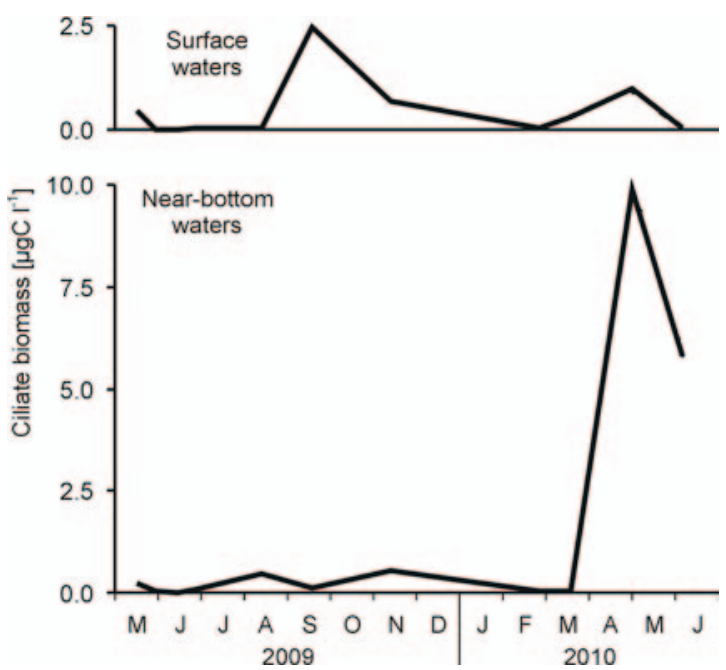

Fig. 1. Seasonal changes in the ciliate biomass in Lake Jasne (Iława Lake District, Northern Poland). The studies were carried out between May 2009 and June 2010

ly Vorticella sp.). On the whole, the ciliate community in the near-bottom zone was more diverse than in the surface waters; prostomatids contributed $54 \%$ of biomass, peritrichs $-11 \%$, and oligotrichs $-4 \%$. Scuticociliates constituted only $1 \%$, whereas $30 \%$ of the biomass included other orders and unidentified specimens (small in number yet typically large in size, and therefore, constituting significant biomass). No anoxic ciliates were recorded.

The strong dominance of prostomatids and the marginal role of oligotrichs both in the surface waters and in the near-bottom zone are rather unusual. Other studies done in oligotrophic waters (Beaver and Crisman 1982, Pfister et al. 2002, Obolkina 2006) described ciliate communities dominated by oligotrichs. Ciliates differ in their $\mathrm{pH}$ tolerance (Pedersen and Hansen 2003, Weisse and Stadler 2006) and the composition of the ciliate community in Lake Jasne could be a result of low $\mathrm{pH}$ of the water (4.0-4.8, Burkowska and Donderski 2006). Packroff (2000) studied protozoan communities in acidic mining lakes and also noted the marginal role of oligotrichs and considerable importance of prostomatids (together with hypotrichs and peritrichs). However, other results were reported by Mieczan (2007), who observed the typical dominance of oligotrichs in acidic peat-bog reservoirs. Similarly, Beaver and Crisman (1981) and Bienert et al. (1991) reported high abundances of oligotrichs in subtropical acidic lakes. As discussed, ciliate communities in oligotrophic acidic waters differ with respect to their 
composition, and therefore, further studies on the topic are necessary. Such studies should include a thorough description of the chemical properties of the waters.

\section{Acknowledgements}

The authors would like to express their gratitude to Stanisław Licznerski for his help with sampling and environmental measurements.

\section{References}

Azam F., Fenchel T., Field J. D., Gray J. S., Meyer-Reil L. A., Thingstad F., 1983, The ecological role of water-column microbes in the sea, Mar. Ecol. Prog. Ser. 10: 257-263.

Beaver J. R., Crisman T. L., 1981, Acid precipitation and the response of ciliated protozoans in Florida lakes, Verh. Int. Ver. Limnol. 21: 353-358.

Beaver J. R., Crisman T. L., 1982, The trophic response of ciliated protozoans in freshwater lakes, Limnol. Oceanogr. 27: 246-253.

Bienert R. W., Beaver J. R., Crisman T. L., 1991, The contribution of ciliated protozoa to zooplankton biomass in an acidic, subtropical lake, J. Protozool. 38: 352-354.

Burkowska A., Donderski W., 2006, Influence of pH on the development of heterotrophic bacteria in presence of humic substances, Limnol. Pap. 1: 81-88.

Carrick H. J., Fahnenstiel G. L., 1990, Planktonic protozoa in lakes Huron and Michigan: seasonal abundance and composition of ciliates and dinoflagellates, J. Great. Lakes Res. 16: 319-329.

Foissner W., Berger H., 1996, A user-friendly guide to the ciliates (Protozoa, Ciliophora) commonly used by hydrobiologists as bioindicators in rivers, lakes, and waste waters, with notes on their ecology, Freshwater Biol. 35: 375-482.

Jańczak J. (ed.), 1997, Atlas jezior Polski (The atlas of Polish lakes), Bogucki Scientific Publisher, Poznań, p. 256 (in Polish).
Mieczan T., 2007, Relationships among ciliated protozoa and water chemistry in small peat-bog reservoirs (Łęczna-Włodawa Lakeland, Eastern Poland), Oceanol. Hydrobiol. Stud. 36: 77-86.

Obolkina L. A., 2006, Planktonic ciliates of Lake Baikal, Hydrobiologia, 568(S): 193-199.

Packroff G., 2000, Protozooplankton in acidic mining lakes with special respect to ciliates, Hydrobiologia 433: 157166.

Pedersen M. F., Hansen P. J., 2003, Effects of high pH on a natural marine planktonic community, Mar. Ecol. Prog. Ser. 260: 19-31.

Pfister G., Auer B., Arndt H., 2002, Pelagic ciliates (Protozoa, Ciliophora) of different brackish and freshwater lakes a community analysis at the species level, Limnologica 32: 147-168.

Sherr E. B., Sherr B. F., 2002, Significance of predation by protists in aquatic microbial food webs, Antonie Leeuwenhoek 81: 293-308.

Šimek K., Jürgens K., Nedoma J., Comerma M., Armengol J., 2000, Ecological role and bacterial grazing of Halteria spp.: small freshwater oligotrichs as dominant pelagic ciliate bacterivores, Aquat. Microb. Ecol. 22: 43-56.

Swiontek-Brzezinska M., Donderski W., 2006, Chitinolytic bacteria in two lakes of different trophic status, Pol. J. Ecol. 54: 295-301.

Turley C. M., Newell R. C., Robins D. B., 1986, Survival strategies of two small marine ciliates and their role in regulating bacterial community structure under experimental conditions, Mar. Ecol. Prog. Ser. 33: 59-70.

Utermöhl H., 1958, Zur Vervollkommnung der quantitativen Phytoplankton-Methodik, Mitt. Int. Ver. Limnol. 9: 1-38.

Weisse T., Stadler P., 2006, Effect of pH on growth, cell volume, and production of freshwater ciliates, and implications for their distribution, Limnol. Oceanogr. 51: 17081715.

Yasindi A. W., Taylor W. D., 2003, Abundance, biomass and estimated production of planktonic ciliates in Lakes Victoria and Malawi, Aquat. Ecosyst. Health Manage. 6: 289-297. 
